\title{
SPECTROPHOTOMETRIC DETERMINATION OF URANIUM(IV) WITH ARSENAZO III
}

ELIZABETH W. BAUMANN

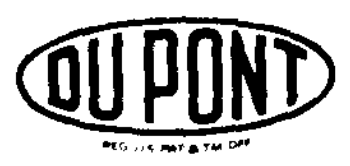

E. I. du Pont de Nemours \& Co. Savannah River Laboratory

Aiken, SC 29808 


\section{DISCLAIMER}

This report was prepared as an account of work sponsored by the United State Government. Nelther the United States nor the Unlted Steter Department of Energy, nor any of thair employees, make eny warranty. express or implied, or asumes eny leas libbllity or responsibility for the eccurecy, completencas, or usefulnose of any informetion, apperatus, pro. duct, or procese disclosed, or represents that its use would not infringe privately owned righte. Feference nerein to eny epeclfic commercial product, process, or service by trade name, merk, manufacturer, or otherwie does not necesarily constitute or imply its ondorsement, recommendation, or fevoring by the United Stetes Government or env agency thereof. The viewe and opinions of authore expresed herein do not necesearily state or reflect those of the United States Government or any soency thereof.

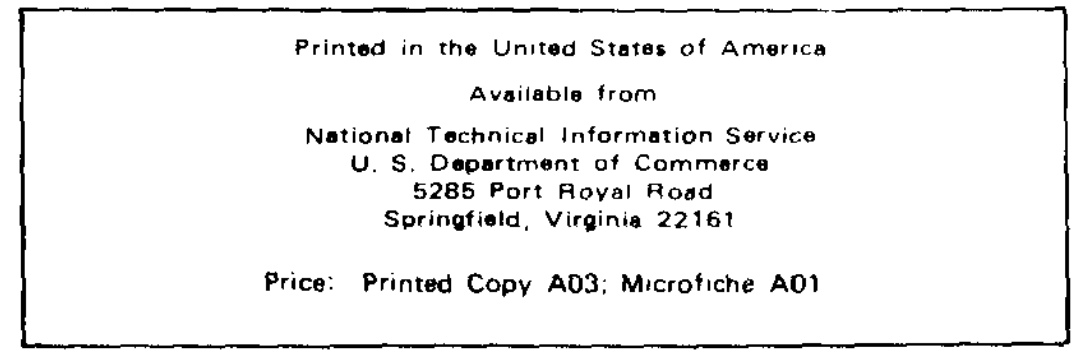




\section{SPECTROPHOTOMETRIC DETERMINATION OF URANIUM(IV) WITH ARSENAZO III}

\section{ELIZABETH W. BAUMANN}

Approved by

M.L. Hyder, Research Manager

Analytical Chemistry Division

Publication Date: July 1980

\section{Issued by E. I. du Pont de Nemours 8. Co. Savannah River Laboratory \\ Aiken, SC $\mathbf{2 9 8 0 8}$}

PREPARED FOR THE U. S. DEPARTMENT OF ENERGY UNDER CONTRACT DE-ACO9.76SR00001 
A spectrophotometric procedure was developed for determining $U$ (IV) in the presence of $U(V I)$ by forming a colored complex with Arsenazo III in $4 \mathrm{M} \mathrm{HCl}$. The results compare satisfactorily with U(IV) determinations by ceric titration. Total uranium can be determined after reduction of $U(V I)$ with metallic zinc. The concentration range for the absorbance cell solution is 0 to $2 \mu \mathrm{g}$ U(IV)/mL. Other tetravalent lons, such as thorlum, zirconium, hafnium, plutonium, and neptunium, will interfere. 
Introduction 5

Background 5

Procedure 7

Results 8

Appendix 11

References 15 


\section{INTRODUCTION}

Tetravalent uranium [U(IV)] is a reducing agent that has potential application as a holding reductant in nuclear fuel reprocessing. In the presence of U(IV), plutonium is maintained as $\mathrm{Pu}$ (III), which is not extractable into the organic phase (tributylphosphate in n-paraffin). Use of $U(I V)$ as the reductant avoids addition of foreign ions into the extraction system, which later will add to the waste volume. Details of the preparation of U(IV) salts by electrolytic reduction ${ }^{1}$ and their usage in reprocessing applications ${ }^{2}$ are discussed elsewhere.

The method that is currently in use for determination of $U(I V)$ consists of a redox titration with ceric ammonium sulfate and ferroin indicator. ${ }^{3}$ This method has the following limitations: 1) relatively large amounts of U(IV), and thus of radioactive sample, are needed; 2) $\mathrm{Pu}$ (III) is also oxidized by $\mathrm{Ce}$ (IV), so that only the total Pu(III) + U(IV) can be determined; 3 ) hydrazine, which is added as a stabilizer and nitrite scavenger, makes the end point somewhat indefinite; and 4) titration of U(IV) in the organic phase has a relatively slow end point.

The objective of the present work was to develop a simple procedure for colorimetric determination of U(IV) that would not have the limitations of the ceric titration. The work was prompted by the report ${ }^{4}$ that a highly colored complex is formed by U(IV), but not by $U(V I)$ or $\mathrm{Pu}(\mathrm{III})$, with Arsenazo III (Ar) in strong acid solution.

\section{BACRGROUND}

Arsenazo III, which has the structure<smiles>O=C(O)[C@@H]1CCC=CC1N=Nc1c(S(=O)(=O)O)cc2cc(S(=O)(=O)O)c(N=Nc3ccccc3S(=O)(=O)O)c(O)c2c1O</smiles>

forms highly colored complexes with many metal ions. Therefore, it $f$ inds use in many colorimetric methods. Although relatively non-selective at lower acidities, selectivity of Arsenazo III increases in strongly acid solutions ( $>4 M$ ) for a number of elements in their tetravalent state ( $U, \mathrm{Th}, \mathrm{Zr}, \mathrm{Hf}, \mathrm{Pu}$, and $\mathrm{Np}$, for example) that would otherwise be hydrolyzed. Thus, in $4 \mathrm{M} \mathrm{HCl}$, determination of $U(I V)$ in the presence of $U(V I)$ becomes feasible. 
Figure 1 shows the absorption spectra of the Ar reagent and of the U(IV) complex in the region of the absorption maximum of the complex. Although Ar reagent itself is highly colored (pink), its absorbance is minimal in the region of. maximum absorbance ( 660 to $670 \mathrm{~nm}$ ) of the green-blue U(IV) complex. The molar extinction coefficient of the complex is about 100,000 .

The 1:2 complex has a much higher extinction coefficient than the $1: 1$ complex. 5 Therefore, a large (e.g., 10-fold) excess of Arsenazo reagent is needed to ensure formation of the 1:2 complex.

The colored metal complex is relatively stable. However, oxidizing and strong reducing agents attack the reagent and must be absent. In nitric acid systems, for example, addition of urea to scavenge nitrous acid is recommended. 6

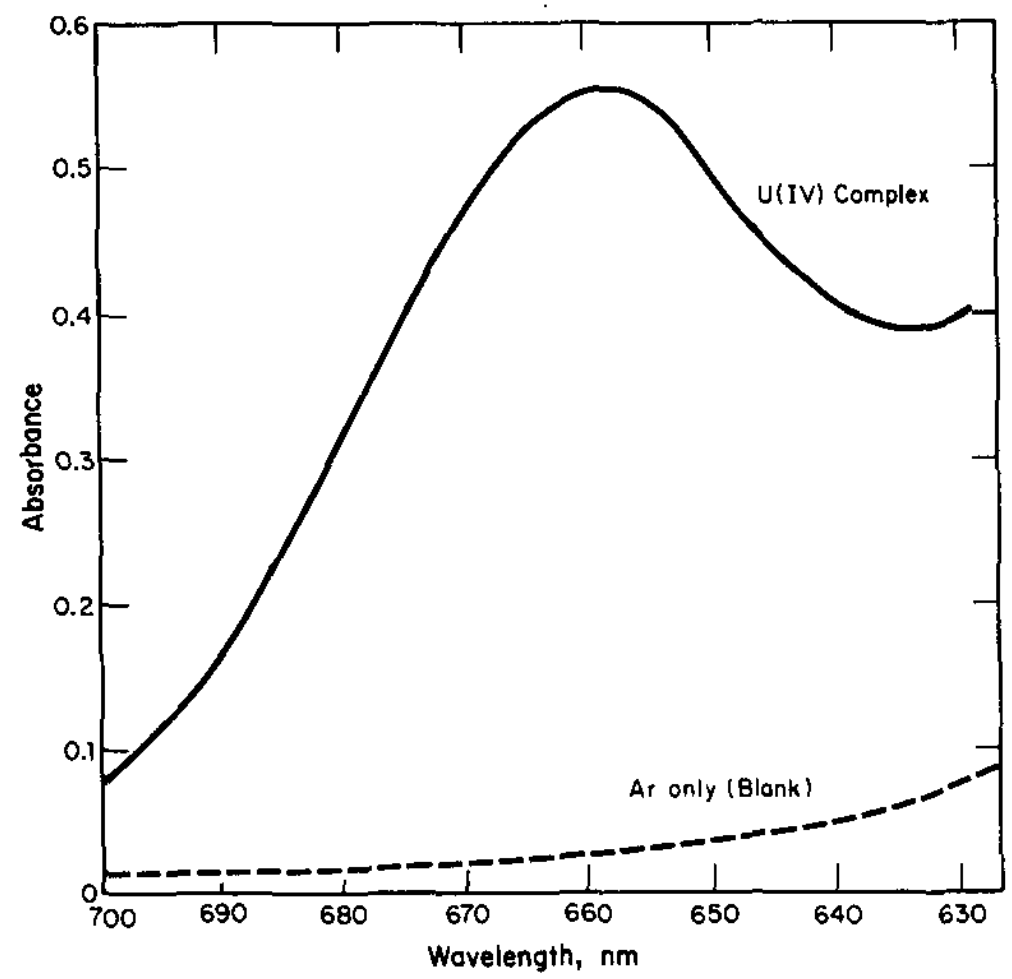

FIGURE 1. Absorption Spectra with Arsenazo III (4M HCl) 


\section{PROCEDURE}

The essence of the detailed analytical procedure, given in the appendix, is addition of Ar reagent to aqueous U(IV) solution in $4 \mathrm{M} \mathrm{HCl}$, followed by determination of the absorbance of the colored complex at $663 \mathrm{~nm}$. Determination of U(IV) in the organic phase ( $30 \%$ tributylphosphate in n-paraffin) involves prior extraction into $4 \mathrm{M} \mathrm{HCl}$ that contains ascorbic acid. The color is stable more than 30 minutes. Occasional high blank values were encountered, perhaps a matter of technique. Consequently, water, rather than blank reagent, was used as the reference for the spectrophotometric measurement.

Preparation of Ar reagent to ensure complete dissolution of the Ar crystals appears to be important for stable color formation. Initial experiments with freshly prepared solutions and/or solutions stronger than $0.05 \%$ Ar resulted in rapidly fading absorbances (within minutes) and in some cases in precipitation of the metal complex. As described in the appendix, a suitable $0.05 \%$ reagent was produced by prolonged stirring to dissolve the crystals followed by aging overnight and filtering.

A solution of uranyl nitrate that was standardized by a modified Davies-Gray ${ }^{7}$ procedure served as the standard for the calibration curve (Figure 2). The U(VI) was quantitatively reduced to $U$ (IV) in $4 \mathrm{M} \mathrm{HCl}$ with metallic zinc and ascorbic acid. This reduction procedure can also be used for determination of total uranium.

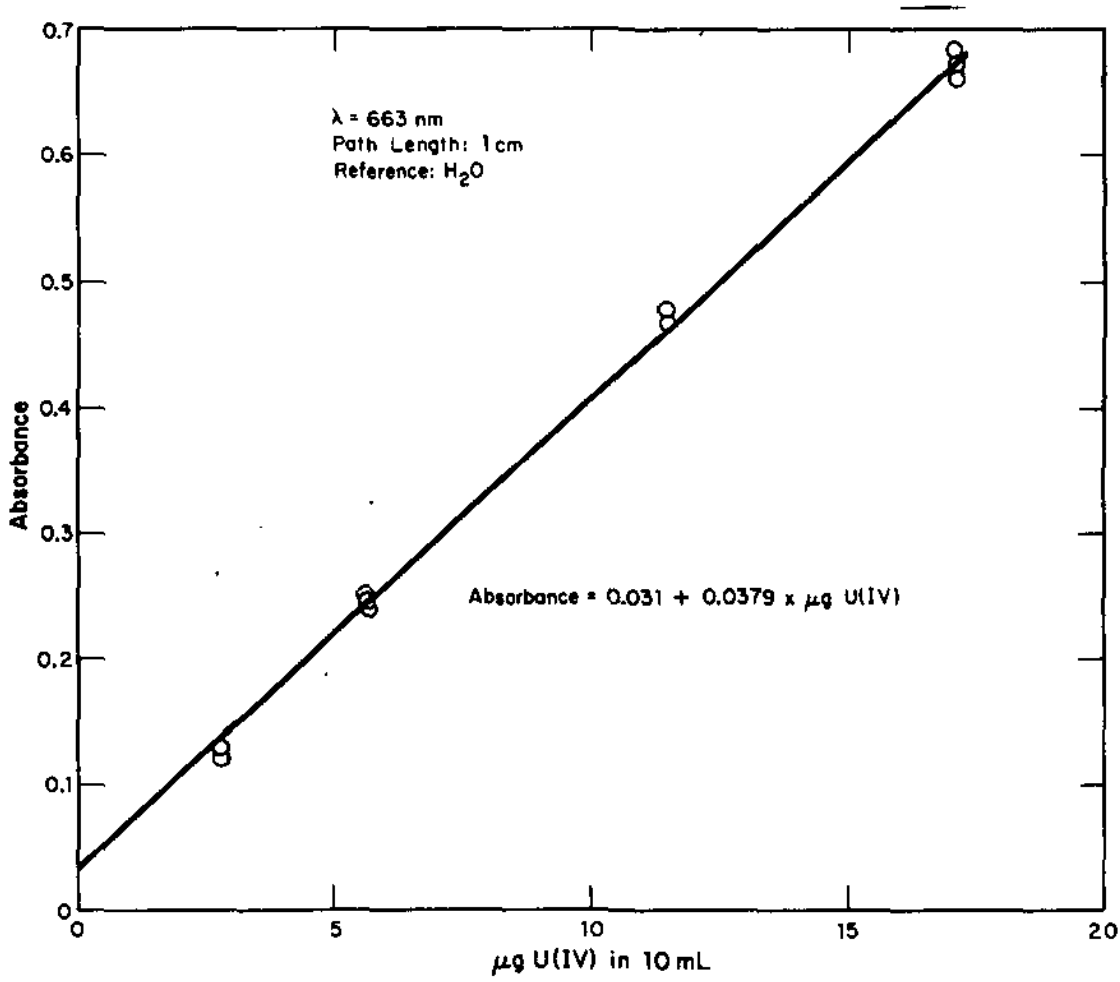

FIGURE 2. Standard Curve for Determination of U(IV) with Arsenazo III 
Because Ar is a non-selective reagent, tetravalent thorium, plutonium, zirconium, hafnium, and neptunium constitute potential interferences. It was beyond the scope of this work to establish procedures to deal with interferences. However, zirconium can be masked with oxalate. ${ }^{4}$ U(IV) could be determined in the presence of thorium as the difference between two determinations: 1) U(IV) $+\mathrm{Th}$, on the untreated sample and 2) Th only, after oxidation of $U(I V)$ to U(VI). Other selective oxidation schemes could be used to distinguish U(IV) from $\mathrm{Pu}(\mathrm{IV})$, or to determine U(IV) in the presence of other oxidizable or reducible metal ions.

\section{RESULTS}

A typical calibration curve is shown in Figure 2 . The concentration is 0 to $20 \mu \mathrm{g}$ of $\mathrm{U}$ (IV) in the $10-\mathrm{mL}$ volume used. Precision diminishes at higher uranium concentrations. A linear least squares $f i t$ of the data gives a reagent blank of about 0.03 absorbance units.

The procedure was demonstrated with three solutions of uranium (IV) nitrate prepared by the electrolytic process. 1 These solutions contained about $1 \mathrm{M} \mathrm{HNO}_{3}$ and $0.2 \mathrm{M}$ hydrazine. The time between $U(I V)$ preparation and these analyses ranged from less than 3 weeks to 19 months.

Table 1 compares the results from U(IV) determinations by the colorimetric method and by titration with ceric ammonium sulfate. ${ }^{3}$ The exact end point in the titration was difficult to establish because of fading, probably caused by hydrazine or other reducing agents in the sample solutions. The fading end point was most troublesome in the oldest sample. Because of this problem, the accuracy of the titration values is open to question. Despite this uncertainty, values obtained with the two methods agree satisfactorily.

Table 2 illustrates recovery of $U($ IV) from the organic phase. The organic solution was prepared by quantitatively extracting U(IV) from an aliquot of Sample 1 (Table 1), through successive extractions with $30 \%$ tributylphosphate in n-paraffin. This organic solution was diluted to a known volume; then an aliquot was back-extracted into $4 \mathrm{M} \mathrm{HCl}$ that contained ascorbic acid to stabilize the U(IV). Table 2 shows that a single extraction of the aliquot with $3 \mathrm{~mL}$ of $4 \mathrm{M} \mathrm{HCl}$ was generally sufficient to remove the U(IV). The absorbance of the second extraction was in the region of the reagent blank. Direct formation of the colored complex in the organic phase was not investigated. 
TABLE 1

U(IV) Determinations

\begin{tabular}{|c|c|c|c|c|}
\hline \multirow[b]{2}{*}{ Sample } & \multirow[b]{2}{*}{ Age } & \multirow{2}{*}{$\begin{array}{l}\text { Sample } \\
\text { Size, } \mu \mathrm{L}\end{array}$} & \multicolumn{2}{|c|}{$\begin{array}{l}\text { U(IV) Concentration, } \\
\mathrm{M} \pm 95 \% \text { C.L. }\end{array}$} \\
\hline & & & Arsenazo & Ce Titration \\
\hline 1 & $<7$ weeks & $25-100$ & $\begin{array}{l}0.152 \pm 0.010 \\
0.154 \mp 0.008 *\end{array}$ & $0.155 \pm 0.002$ \\
\hline 2 & 19 months & $25-100$ & $0.141 \pm 0.007$ & $0.131 \pm 0.002$ \\
\hline 3 & $<3$ weeks & $2.5-5$ & $1.24+0.04$ & $1.15 \pm 0.01$ \\
\hline
\end{tabular}

* From organic phase.

TABLE 2

Determination of U(IV) In Organic Phase* [U(IV) from Sample 1]

\begin{tabular}{|c|c|c|c|}
\hline \multirow{2}{*}{$\begin{array}{l}\text { Sample } \\
\text { Size, HL }\end{array}$} & \multicolumn{2}{|c|}{$\begin{array}{l}\text { Absorbance after } \\
\text { Extraction }\end{array}$} & \multirow{2}{*}{$\begin{array}{l}\text { Calculated U( IV) } \\
\text { Concentration } \\
\text { in Sample 1, M }\end{array}$} \\
\hline & First & Second & \\
\hline 100 & 0.329 & 0.023 & 0.166 \\
\hline 100 & 0.308 & 0.032 & 0.161 \\
\hline 100 & 0.299 & 0.034 & 0.155 \\
\hline 200 & 0.604 & 0.038 & 0.143 \\
\hline 200 & 0.546 & 0.031 & 0.151 \\
\hline 200 & 0.536 & 0.036 & 0.150 \\
\hline
\end{tabular}

* Extracted into 4M HCl prior to color formation.

** $\pm 95 \%$ confidence limit. 
PROCEDURE FOR

DETERMINATION OF URANIUM(IV) WITH ARSENAZO III

Apparatus

Visible spectrophotometer, with $1-\mathrm{cm}$ cells

10-mL volumetric flasks

0.45 -micron filter

Micropipets (10 to $1000 \mu \mathrm{L}$ )

Transfer pipets

Reagents and Standards

Hydrochloric acid ( $\mathrm{HCl}, 4 \mathrm{M})$. Add $150 \mathrm{~mL}$ concentrated $\mathrm{HCl}$ to $300 \mathrm{~mL}$ distilled water.

Arsenazo III, Aldrich Chemical Co., Chemical No. A9, 277-5

$(0.05 \%)$. Weigh $0.05 \mathrm{~g}$ Arsenazo III; add about $1 \mathrm{~mL} 0.1 \mathrm{M}$ NaOH to the solid reagent; allow to stand a few minutes. Dilute to $100 \mathrm{~mL}$ with water and stir for 1 to 2 hours to ensure that the solid is completely dissolved. Allow the solution to stand overnight.

Filter through a $0.45-m i c r o n$ filter. The solution is stable in the absence of oxidizing agents or strong reducing agents.

Zinc metal ( $\mathrm{Zn}$, Reagent-Grade, 10-mesh). Clean a batch of zinc each day before use by adding a few $\mathrm{mL}$ of $4 \mathrm{M} \mathrm{HCl}$ to the $\mathrm{zinc}$ metal

(hydrogen gas is evolved). After about 1 minute, rinse the $z$ inc with water.

Ascorbic acid, solid.

Standard $U(V I)$ solution - for example, $\mathrm{UO}_{2}\left(\mathrm{NO}_{3}\right)_{2}$ solution that has been standardized by the Davies-Gray titration. 7 


\section{Procedure}

1. Place aliquots of uxanium solution in vials containing about $1 \mathrm{~mL} 4 \mathrm{M} \mathrm{HCL}$.

2. Add 10 to 15 granules of 10-mesh zinc.

3. Allow the reaction to proceed for 10 minutes.

4. Add 5 to $10 \mathrm{mg}$ ascorbic acid.

5. Quantitatively transfer the solution to a $10-\mathrm{mL}$ volumetric flask, leaving the $\mathrm{Zn}$ granules behind.

6. Dilute to about $8 \mathrm{~mL}$ with 4M HCl. Mix.

7. Add $1 \mathrm{~mL}$ Arsenazo III reagent. Mix.

8. Dilute to volume with 4M HCL. Mix.

9. Determine absorbance at $663 \mathrm{~nm}$ in a $1-\mathrm{cm}$ cell, with $\mathrm{H}_{2} \mathrm{O}$ in the reference cell.

10. a. For standard curve, plot data (absorbance vs. uranium content).

b. For total uranium, determine uranium content from standard curve.

\section{Comment}

1. The range of uranium should be 0 to $20 \mu \mathrm{g}$.

2. Hydrogen gas is evolved.

3. If gas evolution diminishes or ceases, add more $\mathrm{Zn}$.

4. The ascorbic acid maintains a reducing environment for the U(IV).

5. Use a transfer pipet; rinse the vial twice with $4 \mathrm{M} \mathrm{HCl}$. (Gas evolution will increase when fresh acid is added.)

9. Color is stable for $>30$ minutes.

10. A reasonably straight line should be obtained: typical calibration curve is shown in Figure 2. 
COLORIMETRIC DETERMINATION OF U(IV) IN AQUEOUS PHASE

Procedure

1. Place suitable sample allquot in $10-\mathrm{mL}$ volumetric flask.

2. Dilute to a volume of about $8 \mathrm{~mL}$ with $4 \mathrm{M} \mathrm{HCl}$ that contains a little ascorbic acid. Mix.

3. Add $1 \mathrm{~mL}$ Arsenazo III solution. MIx.

4. Dilute to volume with $4 \mathrm{M} \mathrm{HCl}$. Mix.

5. Measure absorbance at $663 \mathrm{~nm}$ in $1-\mathrm{cm}$ cell, with $\mathrm{H}_{2} \mathrm{O}$ as reference.

6. Determine uranfum(IV) content from standard curve.
Comment

1. Sample should contain 0 to $20 \mu \mathrm{g} \mathrm{U}(\mathrm{IV})$. Volume generally expected to be $<250 \mu \mathrm{L}$.

5. Color is stable for $>30$ minutes. 


\section{COLORIMETRIC DETERMINATION OF U(IV) IN ORGANIC PHASE}

\section{Procedure}

1. Place sultable sample aliquot in extraction vial.

2. Add about $3 \mathrm{~mL} 4 \mathrm{M} \mathrm{HCl}$. Mix on vortex mixer for about 1 minute.

3. When phases have separated, transfer aqueous phase to 10-mL volumetric flask.

4. Repeat Steps 2 and 3.

5. Add $1 \mathrm{~mL}$ Arsenazo III solution. Mix.

6. Dilute to volume with $4 \mathrm{M}$ HCl. Mix.

7. Measure absorbance at $663 \mathrm{~nm}$ in 1-cm cell, with $\mathrm{H}_{2} \mathrm{O}$ in the reference cell.

8. Determine uranium content from standard curve.
Comment

1. Sample should contain 0 to $20 \mu \mathrm{g}$ U(IV).

3. Centrifugation is recommended for a clean phase separation.

7. Color is stable for $>30$ minutes. 


\section{REFERENCES}

1. E. G. Orebaugh and R. C. Propst. Electrolytic Production of Uranous Nitrate. USDOE Report DP-1549, E. I. du Pont de Nemours \& Co., Savannah River Laboratory, Aiken, SC (1980) .

2. Gunter Koch. "Existing and Projected Reprocessing Plants: General Review." Atomkernenergie Kerntechnik 33 (4), 241 (1979).

3. Handbook of Analytical Chemistry. First edition, L. Meites, ed., p. 3-73, McGraw-Hil1 Book Company, New York (1963).

4. S. B. Savvin. "Analytical Use of Arsenazo III - Determination of Thorium, Zirconium, Uranium and Rare Earth Elements." Talanta 8 , 673. (1961).

5. S. B. Savvin. "Analytical Applications of Arsenazo III - III. The Mechanism of Complex Formation between Arsenazo III and Certain Elements." Talanta 11, 7 (1964).

6. A. A. Nemodruk and N. E. Kochetkova. "A Study of the Reaction of Tetravalent Plutonium with Arsenazo III." Zhur. Anal. Khim, $\underline{18} 333$ (1963).

7. W. Davies and W. Gray. "A Rapid and Specific Method for the Precise Determination of Uranium Using Iron(II) Sulphate as Reductant." Talanta 11, 1203 (1964). 